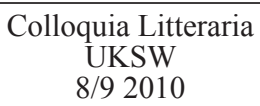

DOMINIKA BUDZANOWSKA

\title{
WOKÓŁ EPIKUREIZMU I LATHE BIOSAS KAZIMIERZA PAWLOWSKIEGO
}

Kazimierz Pawłowski, badacz i znawca średniego platonizmu, tym razem swoją książkę Lathe biosas. Żyj w ukryciu. Filozoficzne postannictwo Epikura z Samos, wydaną przez Towarzystwo Naukowe KUL w Lublinie w 2007 roku, poświęcił - jak zresztą wskazuje sam podtytuł - Epikurowi i jego szkole filozoficznej. Sam tytuł przypomina, że Epikur wzywał do życia ukrytego, oddalonego od zgiełku i thumu. Autor w tym niewielkim (liczącym 108 stron) opracowaniu ciekawie i w różnych aspektach pokazuje epikureizm, opierając się na tak zwanych testimoniach (,świadectwach”) epikurejskich:

Czytajac owe testimonia, usiłowatem odgadnać zagadke filozofii Epikura i jego filozoficznej osobowości. Tak bowiem wyobrażam sobie swoja, jako historyka filozofii, role - tzn. jako próbę przeniknięcia w krag myślowy i osobowy filozofa, w tym w jego krag duchowy, aby (...) zrozumieć jego filozofię niejako z punktu widzenia jego samego, a więc jakby od jej wnętrza i tego, jak ona funkcjonowała w właściwym jej środowisku (s. 93).

Już wstęp dostarcza wielu ważnych wyjaśnień, kluczowych dla zrozumienia myśli filozoficznej Epikura z Samos.

Epikureizm powstał pod koniec IV wieku p.n.e., w epoce hellenistycznej. Zarówno Ogród Epikura (gr. kepos - gdyż w małym domku w ogrodzie mieściła się owa szkoła) jak i kojarzona z nim Stoa Zenona rodziły się $\mathrm{w}$ epoce rozbudzonego indywidualizmu i rosnące- 
go zainteresowania człowiekiem. Obie zrezygnowały z tradycyjnych rozważań nad istotą rzeczy, przyjmując z niewielkimi jedynie zmianami rozwiązania stare. Epikur podążył za Demokrytową doktryną, według której cała rzeczywistość składała się z małych, niepodzielnych atomów, Zenon zaś przejął od Heraklita z Efezu naukę o Ognistym Sensie czy Rozumie Wszechświata. Obie szkoły zwróciły swoją uwagę głównie na zagadnienia praktyczne, szukając odpowiedzi przede wszystkim na palące pytanie, jak człowiek ma żyć i postępować, aby zapewnić sobie szczęście. Obie, głosząc naukę materialistyczną, nie wykluczały jednak istnienia Boga czy też bogów. Obie również walczyły z szerzącym się wówczas sceptycyzmem, usiłując na dwóch odmiennych drogach dać ludziom to, czego nie znajdowali już oni w oficjalnym kulcie polis ${ }^{1}$.

Trzeba bowiem pamiętać, że w okresie hellenistycznym kultura grecka straciła na czystości, zmieszała się z obcymi kulturami. Świat hellenistyczny nie jest wyłącznie światem greckim, jest jakby wielonarodowościowy; współistnieją w nim różne ludy, elity są czysto greckie lub mieszane, gdzie niegdzie przetrwały stare miejscowe elity (np. w Egipcie, Syrii, Azji Mniejszej przy świątyniach, jeden ważny wyjątek to Żydzi w Judei). Część kultur zachowuje swą siłę, niektóre słabną. W tej epoce często świętom nadaje się ramy greckie (sprowadza się grupy teatralne, organizuje się zawody sportowe...). Poza tym wszędzie jest ten sam: język (głównie wzorowany na attyckim - grecka koine), alfabet (nawet krój liter), te same teksty szkolne, ćwiczenia w szkołach, model wychowawczy (wzorowany na Atenach Izokratesa - IV w.), ogromną rolę w kształceniu odgrywa lektura klasycznego zestawu literatury szkolnej (ten ,wykaz lektur szkolnych” przetrwa aż do czasów Bizancjum, trochę tylko się skróci), ćwiczenia retoryczne, jednolity „rynek księgarski” (po miastach krążą trupy teatralne, mówcy z odczytami, tekstami literackimi...). Różnice w gustach elity są niewielkie. Jednolite stają się też takie materialne ramy, jak: ubiór, przedmioty codziennego użytku, ponadto sztuka walki, model administracyjny...

1 Por. A. Świderkówna, Bogowie zeszli z Olimpu. Bóstwo i mit w greckiej literaturze świata hellenistycznego, Warszawa 1991, s. 78. 
Jednak (jak zauważa Tatarkiewicz) w filozofii przewaga greczyzny była ogromna, czynnik obcy doszedł tu do głosu w znikomym tylko zakresie ${ }^{2}$. Czasy hellenistyczne charakteryzują się w filozofii tym, że rozwijała się ona w szkołach, z których każda stanowiła dość zamknięty obóz filozoficzny (jest to epoka raczej walki szkół, ale też prób tworzenia filozofii eklektycznej). Oprócz nowych szkół nadal prężnie działała Akademia Platona i Liceum Arystotelesa. Najbardziej odosobnieni byli właśnie epikurejczycy, jako że ich pozytywny sposób myślenia bardzo odróżniał ich od platończyków, perypatetyków czy stoików.

Epikur, jak podaje Pawłowski we wstępie Lathe biosas, urodził się na wyspie Samos w 341 roku p.n.e., wywodził się z ateńskiego arystokratycznego rodu. Zmarł natomiast w Atenach około 270 roku p.n.e. Ponoć filozofią interesował się już w wieku czternastu lat. Wiadomo, że zetknął się z Pamfilosem, platończykiem, oraz Nauzyfanesem, atomistą. Jednak później nie wspominał ich jako swoich mistrzów. Przypuszczać więc można, że niewiele skorzystał z nauk, pobieranych u nich (por. s. 8). Pawłowski konstatuje o Epikurze: „Doktrynę swoją wykuwał sam - w tym samym czasie, w którym przyszło mu borykać się z trudami życia i znosić ciężary, jakie stały się udziałem ówczesnej Grecji” (s. 8). Epikur bowiem wziął prawdopodobnie udział w wojnie lamijskiej, w każdym razie wtedy (lata 323 - 322 p.n.e.) służył w wojsku. Jak podkreśla Pawłowski:

Zakosztował udręk owych lat we wszystkich ich odmianach i odcieniach. Cierpiał niedostatek, znosił liczne słabości ciała. Choroby, których wówczas się nabawił, nie opuściły go do końca życia. Nieobcy był mu ból potwarzy i szyderstwa, jakich nie szczędzili mu wrogowie. Borykanie się z trudnościami i biedą przyczyniło się zapewne do tego, że Epikur wykuł w sobie te cechy, które stały się nośnikiem jego wielkości jako filozofa, pedagoga i apostoła swego filozoficznego posłannictwa (s. 9).

2 W. Tatarkiewicz, Historia filozofii, t. 1, Warszawa 2005, s. 142. 
Pawłowski od samego początku konsekwentnie twierdzi i udowadnia, że „Filozofia Epikura z Samos jest w dziejach filozofii greckiej, niezależnie od ocen, z jakimi się spotkała, zjawiskiem niezwykłym. Epikur (...) otworzył nowy horyzont myśli filozoficznej. (...) stworzył obraz, jakiego dotąd Grecja nie oglądała" (s. 7). Autor Lathe biosas wyjaśnia, że Epikur miał przeciwników we wszystkich ówczesnych szkołach filozoficznych: „podważał bowiem niemal wszystkie najważniejsze tezy każdej z tych szkół”, a równocześnie „nie tylko z racji swojej nauki, lecz również z powodu swojej nadzwyczajnej dobroci i szlachetności, był bardzo szanowany, a nawet czczony przez swoich rodaków, o czym świadczy niezliczona ilość posagów, jakie mu wystawili” (s. 7). Dalej konstatuje:

Epikur nie był biernym pływakiem niesionym zmiennymi prądami dziejów duchowości greckiej. Był jednym z kreatorów tych dziejów i tej duchowości. (...) Grecja znajduje się w stanie wzburzenia. Ścierają się ze sobą diadochowie na lądzie i morzu, a po obu stronach giną ci sami Grecy. Wojska różnych, ale tą samą owianych ambicją, wodzów przewalają się przez Helladę. Pożoga wojenna nie opuszcza ojczyzny Epikura. Towarzyszy jej to, co zwykle towarzyszy wojnie: strach, głód, cierpienie, śmierć, niewola. (...) o losach ludzi decydują nienasycone ambicje królów. Tradycyjne wartości moralne, szanowane przez Greków, są mocno nadwątlone. Zbrukane zostanie nawet ich poczucie boskości, gdy cześć, należną dotąd tylko bogom, będą okazywać człowiekowi (s. 9).

Epikur kierował swoją naukę do ludzi nieszczęśliwych i do tych, którzy szukali przewodnika duchowego (por. s. 14). W innym miejscu Pawłowski zauważa:

Grek zawsze pyta o to samo: jak być szczęśliwym? Teraz, na początku nowej epoki to pytanie jest bardziej zasadne niż kiedykolwiek przedtem. Grek epoki klasycznej był przede wszystkim 
obywatelem swojego miasta-państwa, na którego los wywierał odczuwalny przez siebie wpływ i którego los był również jego losem. (...) Teraz, a stało się to w przeciagu niemal jednego pokolenia, losy państwa i losy obywatela rozeszły się. Grek nie identyfikuje się z nowym państwem. Nie traci wprawdzie poczucia przynależności narodowej, tym niemniej zostaje niejako pozbawiony fundamentu starych praw i tradycji związanych z polis. Zmuszony jest szukać innego punktu oparcia, innych dróg do swego szczęścia. (...) musi powstać «nowy etos» człowieka - już nie obywatelaczłonka wspólnoty polis, lecz człowieka «indywidualnego». Stoicy wypracowali etos człowieka jako cząstki kosmosu. Z kosmosem nie mogą wiązać go uczucia, więc trzeba było się ich wyzbyć. Szczęście w ujęciu stoickim - to pełne i rozumne zespolenie z tym kosmosem. Epikur zaproponował inny model człowieka - model człowieka fizykalnego, mającego strukturę równie fizykalną jak cały świat, strukturę atomistyczną (s. 13).

Obie tworzyły wspólnoty, w których każdy buduje swoje szczęście u epikurejczyków mocno przesycone uczuciowościąjako stanem przeżywanym, a nie tylko uświadamianym, stanem wyzwalającym uczucie rozkoszy (por. s. 14).

Według nauki Epikura (jego pisma zachowały się tylko we fragmentach $^{3}$ ) żadne rozkosze nie są złem same w sobie, dopóki nie wywoływały jakichś negatywnych skutków. Szczęście zależy przede wszystkim od stanu ducha, stan ciała nie jest najistotniejszy. Przyjemność, którą głosi Epikur, nie płynie z rozpusty ani zmysłowych przyjemności. Charakteryzuje się nieobecnością cierpień fizycznych i brakiem duchowego niepokoju: rolą filozofii jest odnalezienie jedynej prawdziwej przyjemności, czystej przyjemności istnienia, ale w sposób zgodny z rozumem ${ }^{4}$. Trzeźwy rozum, dociekający przyczyn wszelkich wyborów, odrzucający domysły, czyni życie przyjemnym. To mądrość (fronesis) jest początkiem wszelkiego dobra i dobrem naj-

3 Fragmenty pism Epikura i świadectwa pośrednie zebrał po raz pierwszy H. Usener w Epicurea, Lipsia 1887 (Roma 1963).

4 Por. P. Hadot, Czym jest filozofia starożytna?, Kraków 2000, s. 155. 
wyższym, przez co cenniejsza jest niż filozofia, jako źródło wszystkich innych cnót.

Z tą mądrością, jak eksplikuje Pawłowski, wiąże się umiar, o czym pisał sam Epikur w jednym z listów:

Umiarkowanie uważamy za największe dobro nie dlatego, żebyśmy w ogóle mieli poprzestawać na małym, lecz dlatego, abyśmy się nauczyli obywać byle czym, gdy nas bieda nawiedzi, w przeświadczeniu, że najlepiej korzystają z obfitości dobra ci, którzy jej najmniej pożąajają, i że to, co naturalne, jest też łatwe do zdobycia, a to, co urojone, $\mathrm{z}$ trudem trzeba zdobywać. Proste potrawy sprawiają nam tyle samo przyjemności, co wystawne uczty, gdy tylko zostanie usunięte bolesne uczucie głodu. Jęczmienny chleb i woda sprawiają największą rozkosz, jeśli je spożył człowiek głodny (s. 63).

Owo umiarkowanie ma zatem wartość, jako że broni przed zmartwieniami wystawnego życia i zapewnia dobrą kondycję fizyczną i psychiczna, co jest już składnikiem szczęśliwości. Ponadto przysposabia do pełniejszego używania przyjemności, gdy ta już zaistnieje. Według Epikura: „Nie można żyć przyjemnie, jeśli się nie żyje mądrze, uczciwie i sprawiedliwie"s.

Początkowo trzydziestoletni wówczas Epikur uczył w Mitylenie na Lesbos i Lampsakos nad Hellespontem, potem około 307/306 roku p.n.e. przeniósł swą szkołę do Aten, które nadal pozostawały kulturalną stolicą Grecji. (To wydarzenie - nadmienię - Reale nazywa prowokacją wobec wielkich szkół Platona i Arystotelesa, w którym zresztą Epikur widział platonika, oraz początkiem duchowej rewolucji ${ }^{6}$.)

Szkoła Epikura to zarazem wspólnota, gmina epikurejska. Cechą owych wspólnot-gmin epikurejskich był duch wzajemnego szacunku, pomocy (epikurejczycy posiadali np. wspólny majątek - por. s. 10), przyjaźni (nawet wspólnie świętowano rocznice urodzin członków wspólnoty) - była ona dla nich dobrem duchowym (więcej zob.

\footnotetext{
5 C.d. brzmi: ,...[ani nie można żyć mądrze, uczciwie i sprawiedliwie], jeśli się nie żyje przyjemnie"; por. Diogenes Laertios, Żywoty i poglady stynnych filozofów X 140.

6 Por. G. Reale, Historia filozofii starożytnej, t. III, Lublin 2004, s. 178-179.
} 
s. 73-74), panowała w nich swoboda i równość między członkami wspólnoty, także i wtedy, kiedy niektórzy byli niewolnikami, do szkoły Epikura mogli bowiem wstapić wszyscy niezależnie od stanu, wie$\mathrm{ku}$, majątku czy nawet płci. Albowiem do tej szkoły przyjmowano również kobiety:

Jest to prawdziwa rewolucja oznaczająca całkowitą zmianę atmosfery w porównaniu z wyrafinowanym homoseksualizmem panującym w szkole Platona. Tam zresztą także zdarzało się wyjątkowo przyjmować kobiety. W szkole Epikurejskiej należą one jednak do wspólnoty i znajdują się wśród nich nie tylko kobiety zamężne, jak Temista, żona Leontiosa z Lampsaku, ale i kurtyzany, jak Leontion (Lwica), którą malarz Torus przedstawił oddaną medytacjī .

Jak podaje Seneka, nad wejściem do szkoły w Atenach wisiał napis, witający gości i zapraszający do niej jako do miejsca, gdzie dobrem jest najwyższa rozkosz: Hospes, hic bene manebis, hic summum bonum voluptas est (Epistulae 21,10) - Gościu, tutaj będzie ci dobrze, tu dobrem jest najwyższa rozkosz. Pawłowski niewielkie wspólnoty mędrców epikurejskich przyrównuje do oaz spokoju i szczęścia wewnątrz społeczności państwowej, nadto zauważa, iż wzorem dla nich były wspólnoty czy też wspólnota bogów (por. s. 74).

„Gości przysparzał szkole nastrój szlachetnej przyjemności i wzajemnej życzliwości” - pisze Pawłowski (s. 11). I dodaje: „Zanim jednak ów gość zrozumiał istotę epikurejskiej rozkoszy, upłynąć musiał jeszcze długi czas, wypełniony studiami nad filozofią (fizyką i teologia), etyką i kanonika, czyli teorią poznania, a zarazem - czas kształtowania własnego wnętrza i własnych stosunków z innymi ludźmi i całym światem, czyli mówiąc inaczej - czas formacji moralnej duchowej” (s. 12) - dodać można, że takie zapatrywania Pawłowskiego bliskie są poglądom, które reprezentuje Pierre Hadot czy - na gruncie polskim - Juliusz Domański. Pawłowski konstatuje: „Siła nauki Epikura była wielka. Towarzyszył jej osobisty czar filozofa, jego wielka

7 P. Hadot, Czym jest filozofia starożytna?, s. 168; zob. też Pliniusz Starszy, Naturalis historia XXXV 99 i 144. 
osobowość i niezwykła dobroć, którą szczodrze szafował, zyskując sympatię i miłość u ludzi” (s. 16).

Trzeba jeszcze dodać, że epikurejczycy pojmowali filozofię na wskroś praktycznie, nie mogła wystarczać im sama lektura traktatów Epikura, przede wszystkim musieli się ćwiczyć w dyscyplinie pragnień: „Trzeba umieć zadowolić się tym, co łatwo osiagnać, co zaspakaja podstawowe potrzeby bytu, a wyrzec się tego, co zbyteczne. Formuła jest prosta, ale pociagga za sobą zasadniczy zwrot w życiu: zadowalać się prostymi posiłkami, prostym ubiorem, wyrzekać się bogactw, zaszczytów, funkcji publicznych, żyć na uboczu"8. Praktykowanie takich medytacji i ascezy dokonuje się nie w samotności, ale na drodze przyjaźni, zaufania i otwartości, na której to drodze uczniowie i nauczyciele pomagają sobie we wzajemnym dialogu uleczyć swoje dusze $^{9}$. Pawłowski zauważa, że celem Ogrodu nie było tyle wykształcenie umysłu, ile ukształtowanie wewnętrznie bogatej i autonomicznej osobowości, która objawiać się ma we wszystkich zakresach działalności człowieka: teoretyczno-doktrynalnej, praktyczno-etycznej i religijno-duchowej, wypełniając i modelując całe jego życie (por. s. 16).

Epikur wyszedł naprzeciw naturalnym, a często tajonym skłonnościom, kiedy mówił, że najwyższym dobrem jest przyjemność. Do tego nie tylko głosił naukę o szczęściu, lecz (i to jest niezmiernie ważne) także podawał sposób na osiagnięcie tego szczęścia, swoistą metodę, terapię umysłowa, którą przejął od Demokryta z Abdery i rozwinął już samodzielnie. Utrzymywał mianowicie, że przez kontrolę swych myśli i swojej wyobraźni, poprzez odpowiednie rozmyślania, a nade wszystko przez zdobycie racjonalnej wiedzy o świecie i człowieku można osiaggnąc stan spokoju wewnętrznego oraz siłę duchową, utrzymywaną potem dzięki dobrym myślom i czynom oraz wspomnieniom o nich, czyli dzięki swego rodzaju medytacjom. Miało to stworzyć skuteczną ochronę przed cierpie-

\footnotetext{
$8 \quad$ P. Hadot, Czym jest filozofia starożytna?, s. 165.

9 Por. tamże, s. 166; C. Diano, La philosophie du plaisir et la société des amis, w: C. Diano, Studi e saggi di filosofia antica, Padova 1973, s.365-371; A.-J. Festugière, Épicure et ses dieux, Paris 1946, s. 36-70.
} 
niami i wszelkimi rodzaju przykrościami. Swoją tezę oparł Epikur na atomistycznej koncepcji człowieka i na fizyce atomistycznej. Ta ostatnia odgrywała w poglądach epikurejczyków doniosłą rolę, ale nie uprawiano jej wyłącznie dla niej samej, tzn. z pobudek naukowych. Była ona wpleciona w filozoficzne posłannictwo filozofa Ogrodu (s. 15)

- o poszczególnych działach filozofii teoretycznej Epikura (fizyce, etyce i kanonice), a także teologii Epikura szerzej mówią kolejne cztery rozdziały Lathe biosas.

Epikureizm ma też dość wyraźne znamiona religijne - choć przede wszystkim jest szkołą filozoficzną. Podobnie jak ruchy religijne, zwłaszcza misteryjne (bardzo popularne w czasach Epikura), filozofia Epikura pełniła funkcję katharktyczną i soteryjną:

Epikurejska kátharsis dotyczyła sfery pragnień i pożąaná. Soteryjne działanie z kolei zamykało się w świadomości człowieka i poza nią nie wykraczało, a już w ogóle nie wchodziło w obszary eschatologii, kontentując się zupełnie życiem doczesnym, polegało na wybawieniu człowieka $\mathrm{z}$ więzów różnorakich urojeń, lęków, fobii i psychoz religijnych i społecznych. W swej funkcji katharktycznej i soteryjnej filozofia Epikura miała charakter terapeutyczny - leczyła z subiektywnego poczucia nieszczęścia, wywołanego przez fałszywe, niezgodne z rzeczywistą naturą człowieka potrzeby oraz wspomniane fobie i psychozy. (...) Nie ulega wątpliwości, że Epikur był apostołem «zbawczej nauki». Właśnie z tego punktu widzenia przede wszystkim należy widzieć jego filozofię, to jest w perspektywie jego zbawczej (i dodajmy - uwieńczonej sukcesem, jeśli za taki uznać powołanie sporej grupy wyznawców tej filozofii, która przetrwała kilka wieków) misji wobec ludzkości (s. 21).

Dla szkoły Epikura charakterystyczne jest, iż zawsze była wierna nauce swego założyciela i duchowego ojca: „Epikureizm był niewątpliwie potężnym nurtem i szkołą nad wyraz odporną na obce wpływy (...). Uczniowie Ogrodu (...) byli epigonami, których imiona pozostały i musiały pozostać nieznane" (s. 17). Szkoła w samych Atenach 
przetrwała do drugiej połowy I w p.n.e., a jako nurt filozoficzny do drugiej połowy IV wieku, gdy została zwyciężona przez religię chrześcijańską (por. s. 17). Choć epikureizm nigdy nie osiągnął takich szczytów myśli jak platonizm, to ,porwał za sobą wiele umysłów i serc, wprowadzając je na drogę intelektualnego, etycznego i duchowego rozwoju, co przecież tak naprawdę tylko niewielu filozofom europejskim się udało" (s. 21).

Pierre Hadot w swych badaniach nad filozofią starożytną doszedł do wniosku, że wiele trudności w rozumieniu starożytnych dzieł filozoficznych, wynika stąd, że traktuje się je jako przekaz informacji o określonej treści pojęciowej oraz nośnik wiedzy o myśli i psychice ich autora, gdy tymczasem są one zazwyczaj ,ćwiczeniami duchowymi, które autor uprawia sam i które daje do uprawiania czytelnikowi. Są po to, by kształtować dusze. Mają wartość psychagogiczną. Wszelkie twierdzenie powinno być więc rozpatrywane z perspektywy skutku, jaki chce wywołać, a nie jako teza adekwatnie odzwierciedlająca myśl i uczucia jednostki" ${ }^{10}$. Hadot po wielokroć podkreśla, że filozofia, nierozerwalny splot dyskursu filozoficznego ze sposobem życia, jest ćwiczeniem przygotowawczym do mądrości: dąży do mądrości nigdy jej nie osiaga, w pewnym sensie stanowi jej przedsmak ${ }^{11}$.

Koniecznym zatem jest wyraźne zaakcentowanie faktu, że filozofia starożytna wcale nie jest tylko teoretyczna - także, czy wręcz zwłaszcza grecka. Wyraźnie podkreśla to Hadot, który uważa, że historia filozofii nie jest historią poszczególnych filozofii, to jest teoretycznych dyskursów i systemów tworzonych przez filozofów, ale także studium życia filozoficznego i filozoficznych postaw ${ }^{12}$. Hadot nie podważa umiejętności starożytnych filozofów teoretycznego rozważania, choćby i w najdrobniejszych kwestiach epistemologii, logiki czy fizyki, lecz umieszcza tę ich działalność teoretyczną w innej perspektywie niż czynią to współcześni filozofowie. Wyszczególnia w tej kwestii dwa punkty: w pierwszym podkreśla, że począwszy od co najmniej czasów Sokratesa wybór drogi życiowej w procesie filozoficznym nie

\footnotetext{
P. Hadot, Filozofia jako ćwiczenie duchowe, s. 5n.

Por. P. Hadot, Czym jest filozofia starożytna?, s. 26n.

12 Por. tamże, s. 23.
} 
jest ostatnim, ale pierwszym etapem, jest ,wypadkową krytycznej reakcji na inne postawy życiowe, ogólnej wizji pewnego sposobu życia i postrzegania świata oraz własnej dobrowolnej decyzji”'13, a zatem dyskurs filozoficzny bierze się z wyboru życiowego, a nie odwrotnie; w drugim przypomina, że ten wybór życiowy dokonuje się zawsze we wspólnocie, grupie, którą stanowi dana szkoła filozoficzna, a ona z kolei łączy się zwłaszcza z wyborem pewnego sposobu życia, a zatem i ze zmianą w życiu oraz z pragnieniem życia w określony sposób - z takiej perspektywy widać, że teoretyczny dyskurs filozoficzny ma za zadanie objaśnić i racjonalnie umotywować wybór życiowy i wizję świata ${ }^{14}$. Wszak filozofia z języka greckiego etymologicznie oznacza „miłowanie mądrości” (od fileo i sofia). Filozofia zatem to połączenie dwóch elementów: miłości i mądrości.

Pawłowski w swych badaniach naukowych przygląda się tym dwóm elementom z osobna i próbuje zobaczyć, co oznaczały dla samych Greków. W odniesieniu do miłości zwraca uwagę na jej boski aspekt. Przywołując fragment Uczty, przypomina pogląd, że w miłości objawia się dzielność, przez bogów niezwykle ceniona, podziwiana i nagradzana, jak w przypadku Achillesa-miłośnika Patrokla ${ }^{15}$ : „Bo miłośnik ma w sobie raczej coś boskiego (...); bóg w nim przecież mieszka"16. Trzeba bowiem pamiętać, że Eros to bóg i to „z bogów najstarszy i najczcigodniejszy, i najsilniejszy, jeżeli chodzi o zdobywanie dzielności i szczęścia ludzkiego za życia, jak i po śmierci"17. Jest dobry i piękny: „nie masz Erosa w tym, co szpetne jest i złe"18. Cechuje go sprawiedliwość: „Największąjego zaletą jest to, że ani bogom, ani ludziom krzywdy nie czyni, i on nawzajem od nas ani od bo-

\footnotetext{
13 Tamże, s. 25.

14 Por. tamże.

15 Por. K. Pawłowski, Platońskie drogi do boga. Wykład filozofii boga w średnioplatońskiej szkole Gajusa: w: Inspiracje platońskie literatury staropolskiej. Materiaty z konferencji zorganizowanej przez Zespót Badań Literackich nad Historia Kultury Epok Dawnych Instytutu Literatury Polskiej Uniwersytetu Warszawskiego 14-15 października 1998 r., pod red. A. Nowickiej-Jeżowej i P. Stępnia, Warszawa 2000, s. 33n.; o Achillesie por. Platon, Uczta 180 A-B.

16 Platon, Uczta 180 B. Wszystkie cytaty z Uczty w przekładzie W. Witwickiego z wydania: Platon, Uczta, Warszawa 1992.

17 Platon, Uczta $180 \mathrm{~B}$.

18 Platon, Uczta 197 B.
} 
gów krzywdy nie doznaje. (...) każdy go chętnie we wszystkim słucha, a przecież prawa (...) powiadają że sprawiedliwe jest wszystko, co ktoś drugiemu po dobrej woli przyznaje”"19; umiarkowanie: ,przecież umiarkowany to ten, co nad wszystkimi żądzami i rozkoszami panuje, a któraż żądza mocniejsza jest od niego? Jeśli żadna, to chyba on nad nimi panuje, a skoro panuje nad żądzami i nad rozkoszami, musi być ogromnie umiarkowany"20; męstwo: „sam Ares mu się nie oprze, boć nie rządzi Ares Erosem, ale Eros Aresa ma w ręku i ciagnie go do Afrodyty, jak powiadają. A zawsze więcej wart ten, co drugiego ma $\mathrm{w}$ ręku, niż ten, co jest w ręku drugiego. A kto ma w ręku najmężniejszego z mężnych, sam musi być najmężniejszy ze wszystkich"21; wreszcie mądrość: „Ten bóg, jako twórca, jest tak mądry, że i innych twórcami czyni. Kogo tylko Eros nawiedzi, ten się twórcą staje, choćby nigdy przedtem nie miał nic wspólnego z Muzami. (...) sztukę strzelania z łuku i sztukę lekarską, i wieszczbiarstwo wynalazł Apollo tylko dlatego, że go w tym kierunku wiódł Eros-pragnienie. Więc Eros i jego tych rzeczy nauczył, a podobnie u niego się Muzy uczyły muzyki, Hefajstos - kowalstwa, Atena - tkactwa, Zeus - rządzić bogami i ludźmi"'22.

Powracając do wątku dzielności miłosnej, zauważyć należy za Pawłowskim, odwołującym się tu do dialogu Platona Fajdros ${ }^{23}$, że jest ona cenna i szlachetna, a to dlatego, że miłość to „boskie szaleństwo, osobliwe natchnienie zesłane przez samych bogów (i dlatego pewnie przez nich cenione), najszczęśliwsze ze wszystkich szaleństw (...) Wartość miłości bierze się zatem stąd, że jest ona darem bogów. (...) Miłość zatem (ale tylko ta prawdziwa, zesłana przez bogów) ma w sobie coś boskiego; jest czymś świętym, należy do sfery sacrum. Kochać to tyle, co uczestniczyć w sferze wartości boskich. (...) Dzięki miłości - powiedzmy to wprost - człowiek bierze udział w kreatywnej mocy i twórczości samego Boga"24.

\footnotetext{
19 Platon, Uczta 196 B-C.

20 Platon, Uczta 196 D.

21 Platon, Uczta 196 D.

22 Platon, Uczta 196 E i 197 A-B.

23 Por. Platon, Fajdros 244 A, 245 B, 265 B.

24 K. Pawłowski, dz. cyt., s. 34 n.
} 
Następnie Pawłowski zwraca uwagę na jeszcze jeden aspekt miłości, o którym mówi w Uczcie Pauzaniasz ${ }^{25}$ : zakochani dziwnie się zachowują - zresztą bez zgorszenia kogokolwiek, a wręcz za społecznym (i prawnym ${ }^{26}$ ) pozwoleniem. Podobnie zachowywać się będzie wielu filozofów. Owa śmieszność czy dziwaczność filozofów znalazła swe określenia, jak podaje Domański, w przymiotniku atopos oraz w rzeczowniku atopia ${ }^{27}$. Atopia ta może być również uznana za główną ideę apoftegmatów, spisywanych przez starożytnych doksografów, takich jak Diogenes Laertios. W apoftegmatach filozoficznych - jak zauważa Domański - sednem był paradoks i właśnie atopia:

Jedno i drugie z kolei jest nieodłącznie związane z tym układem, który co najmniej od czasów Platona stanowił istotę antycznej filozofii. Filozofia była «atopiczna» i paradoksalna zarazem, odkąd próbowała dotrzeć, poprzez zjawiska, do ukrytej rzeczywistości prawdziwej, rzeczywistości fundamentalnej. Była taka wtedy, gdy dążyła do odkrycia prawdziwych wartości i ustanowienia ich prawidłowej gradacji. Była taka także wtedy, gdy formułowała i głosiła zasady mówiące o sposobie życia zgodnym z wartościami uznanymi przez filozofów. Była taka wreszcie wtedy, gdy realizowała je w życiu i zachowaniu zarówno intelektualnym, jak i moralnym, zawsze zadziwiającym, zawsze paradoksalnym $\mathrm{i}$ «atopicznym», tych, którzy zwali się filozofami i rzeczywiście nimi byli² ${ }^{28}$.

Pawłowski zauważa bliskość miłości i filozofii, jako że obie są jakimś szaleństwem duchowym od bogów ${ }^{29}$, żarem duszy, która odtąd widzi już tylko przedmiot swej miłości; są pewną postacią natchnienia boskiego, co przejawia się jako atopiczność, czyli dziwaczność, osobliwość. Szaleństwo to jest twórcze, jak czytamy u Platona: „największe dobra zawdzięczamy szaleństwu, które, co prawda, bóg nam zsy-

\footnotetext{
25 Por. Platon, Uczta $178 \mathrm{D}-179 \mathrm{~B}$.

Por. Platon, Uczta 1183 C.

7 Por. J. Domański, Metamorfozy pojęcia filozofii, Warszawa 1996, s. 17.

Tamże, s. 19.

29 Por. Platon, Fajdros 265 A-B.
} 
łać raczy"30. Miłość zatem i filozofia są aktami, twórczością duchową i to związaną w jakiś sposób $\mathrm{z}$ bogiem ${ }^{31}$.

Pojawia się jednak pytanie: miłość ma charakter osobowy, kocha się osobę - czy filozofia, kochając mądrość, jest relacją osobową? Kazimierz Pawłowski wyjaśnia, że mądrość w greckiej kulturze duchowej była pojęciem bardzo pojemnym. Początkowo oznaczała pewną intelektualną zdolność do rozwiązywania zagadek, przynależną mędrcom (archetypem by mógł tu być mityczny Edyp, rozwiązujący zagadkę Sfinksa) i bogom. Wkrótce nabrała jednak również zabarwienia etycznego (etyczno-praktycznego) i duchowego ${ }^{32}$. Pawłowski przywołuje legendę o trójnogu, zapisaną przez Diogenesa Laertiosa: trójnóg miał napis „dla mędrca”, posłano go Biasowi (za to, że wykupił z niewoli dziewczęta messeńskie, wychował je, a wreszcie obdarowane posagiem odesłał do rodziców), ten zaś złożył trójnóg w ofierze Apollinowi. Ta historia pokazuje, że (jak miał powiedzieć Pitagoras) „żaden człowiek nie jest mądry, mądry jest tylko bóg" ${ }^{33}$. Mądrość zatem powraca do swych boskich korzeni.

Filozofia skupiła w sobie trzy wymiary: intelektualny, etyczny i duchowy: „Mądrość filozofa nie mogła zatem ograniczyć się tylko do rozumienia i rozwiązywania teoretycznych problemów filozoficznych. Musiała znaleźć swój wyraz również w sferze etyczno-praktycznej i duchowej", przy czym Pawłowski, badając poglądy szkoły średnioplatońskiej, zauważa, że w tym ostatnim aspekcie mądrość nabierała również cech misteryjnych, a nawet mistycznych, prowadziła bowiem do samego boga. Ostatecznie mądrość okazuje się w sensie absolutnym samym bogiem, a zatem filozofia - relacją osobową: miłowaniem mądrości, którą jest bóg ${ }^{34}$. Kazimierz Pawłowski w odniesieniu do epikureizmu konstatuje, iż ta filozofia nosi wręcz wszystkie znamiona posłania i to zwłaszcza posłania religijnego (s. 94).

\footnotetext{
30 Platon, Fajdros 244 A. Wszystkie cytaty z Fajdrosa w przekładzie W. Witwickiego z wydania: Platon, Dialogi, w przekładach W. Witwickiego, wybrał, tekst przejrzał, przedmową i objaśnieniami opatrzył A. Lam, Warszawa 2004.

31 Por. K. Pawłowski, dz. cyt., s. 35.

32 Por. tamże, s. 36.

33 Diogenes Laertios, Żywoty i poglady stynnych filozofów I 12.

34 Por. K. Pawłowski, dz. cyt., s. 37.
} 